DOI: $10.20472 / E F C .2020 .013 .021$

\author{
MARTIN ZEMAN \\ University of Economics, Prague, Czech Republic \\ JAN KOZAK \\ University of Economics, Prague, Czech Republic \\ STEPAN PEKAREK \\ University of Economics, Prague, Czech Republic \\ JAN VONDRACEK \\ University of Economics, Prague, Czech Republic \\ MIROSLAV SEVCIK \\ University of Economics, Prague, Czech Republic
}

\title{
FISCAL RESPONSIBILITY AND DEBT SUSTAINABILITY. PREPAREDNESS FOR EXTERNAL SHOCK: THE CASE OF THE CZECH REPUBLIC AND SLOVAKIA
}

\begin{abstract}
:
The article compares the development of the main government debt indicators in the Czech Republic and in Slovakia between 2014 and 2019 while evaluating their respective positions in the beginning of the crisis caused by the spread of Covid-19 in early 2020. After a review of the characteristics and the nature of the external shock in comparison to previous crisis which took place from 2008 to 2009, the article discusses the preparedness of both economies for negative external shocks, primarily from the public finance perspective. The authors conclude that the Czech fiscal position is one of slightly higher overall preparedness to overcome possible economic problems than that of its Slovak counterpart. However, further assessment of the underlying tensions within Czech government deficit structure, past procyclical economic policy behavior and recent policy actions lessen the superiority of the Czech fiscal position and render both economies equally exposed to the negative effects of the coming crisis. In the current environment of uncertainity, it is difficult to establish a conclusive projection but the authors highlight the key risk areas for the medium-term horizon in the concluding discussion of the paper.
\end{abstract}

Acknowledgment: The publication of this article was supported by the University of Economics, Prague research grant IGA no. IG504020

\section{Keywords:}

Covid-19; Fiscal Policy; General Government; Debt Management; Business Cycle

JEL Classification: H63, E62 


\section{Fiscal policy under the influence of exogenous shock}

The term financial crisis refers to crises whose causes are not found in the real economy but arise from the financial system. The very nature of the crisis in 2008 was different from that of 2020 . The global financial crisis of 2008 is often referred to as the US mortgage crisis, but this name refers only to the market in which the crisis developed first. The true essence of this systematic global crisis lay in the debt problem, which had long been obscured by the mass use of financial innovations, primarily structured credit products in securitized form. The strong economic growth before 2008 was largely based on the massive credit expansion that began in 2001, when Alan Greenspan prescribed a policy of cheap money and the continuous lowering of key interest rates in response to the massive US stock market crash caused by the 9/11 terrorist attacks. This colossal investment wave led stock market recovery and to an increase in consumer and mortgage loan activity. The securitization of private debt, which can be considered the systemic change of this period, had major negative consequences: it increased credit expansion, increased the anonymization of creditor-debtor relationships and therefore obscured clarity about who bears the risk of loss. This problem was accompanied by moral gambling (Buchanan, Tullock, 1962, Stigler, 1971, Peltzman, 1976) on the credit markets, where government guarantees of unhealthy loans only increases the overall volume of such loans through the distortion of the criteria used to allocate domestic and foreign savings and reduces its efficiency while the costs of unsuccessful credit transactions (especially large-scale credit transactions) are essentially socialized and transferred to the public finance system (Guitián, 1992, Cline, 1995, Dvořák, 2008).

This systemic global crisis affected all the economies of the European Union. The depth of its impact, however, differed from country to country. Both the Czech and Slovak economies are open economies. Due to the relative stability of their financial sectors, neither economy was affected by developments in the financial sector itself but by the associated drop in confidence about further positive economic development and the continuing negative developments in foreign economies (primarily the economic downturn in Germany, which remains the key foreign partner for both economies). Dornbusch, Claessens and Park (2002) specify the transmission of positive or negative shocks between countries based on financial, real world, and political routes of contagion. For both investigated countries, the crisis was an imported crisis, the real foundation of which lay in foreign markets.

At the beginning of 2020, economic growth dynamics in the Czech Republic were at their lowest since the crisis of 2008 and the economy had passed its peak in the economic cycle. The slowdown in the economic performance of the Czech economy was clearly noticeable, despite unemployment rates being at a historical low. Economic growth was being driven by domestic consumption, stemming from 
recent strong wage growth. At the beginning of the year, an employee shortage was considered the primary barrier to further extensive production growth in the Czech Republic (MF ČR, 2020). The slowdown in economic growth was also evident also in Slovakia at this time and a clean-up of the market was to be expected. Year-on-year industrial enterprise revenues decreased in the last quarter of 2019 by more than $5 \mathrm{pp}$ and overall GDP growth also slowed. The Slovak labor market, in the same way as the Czech one, was considered one of the barriers to extensive growth. The number of job vacancies in this period was record-breaking but they no longer pushed unemployment down, and nominal wage growth stagnated at $7 \%$. (MF SR, 2020)

The emerging crisis of 2020 is based on different economic foundations to that of 2008. In the first two quarters, the world economy has been hit by an expanding SARS-CoV-2 pandemic, first in the Asian markets, followed by the European Union markets and then followed by the markets of both North and South America. To curb the explosive increase in the number of infected, governments adopted unprecedented restrictive measures that led not only to massive interruption of production but also restricted the movement and therefore the behavior of consumers. These restrictive measures will almost certainly trigger a global economic recession in the coming quarters. Even now, three months since government restrictions were first introduced, quantifying the effects is not possible, primarily because economic behavior has not yet returned to the previous status quo and consumer behavior is still affected by the restrictive measures introduced by individual governments. The very nature of this exogenous shock arose, unlike 2008, in the real world, outside of the financial market.

Using fourth generation financial crisis modelling (Radetel, Sachs, 1998, Mishkin, 2001, Krugman, 2000), it is possible to define a trigger moment in both the 2008 case and in the 2020 case. A trigger tends to be a specific economic, political, or psychological factor, the consequences of which spark a crisis from a latent critical state (Dvořák, 2008). In 2008, the trigger was the bursting of the housing bubble, in 2020 it was an exogenous factor in the form of a global pandemic. Due to interconnected asset markets, banking markets, currency markets and foreign lending operations, the financial contagion has spread and is still spreading to individual national economies. The transmission mechanism between the real economy and financial markets works in both directions.

\section{Government debt sustainability}

Government debt is one of the key indicators of this public finance stability analysis. Operating with a government budget deficit has become an economic policy norm over the past two decades and the latent threat of a debt crisis or a debt trap (Bednáŕ, 2018) has emerged, especially for highly indebted EU countries (Ševčíková, 2015). 
Graph 1. Government consolidated gross debt 2014-2019 and accumulated fiscal space (as \% of GDP)


Source: Eurostat 2020 and own calculations. Left panel: MC (60\%) represents the Maastricht convergence criteria threshold of government debt-to-GDP. Right panel: Fiscal space is calculated as the difference between actual government consolidated gross debt in \% of GDP and Maastricht convergence criteria of $60 \%$.

Graph 1 (Left panel) shows the development of government debt-to-GDP ratios. While we can observe that both countries remain below the Maastricht threshold of $60 \%$ and that both follow a decreasing trend over the observed period, the Czech Republic displays a significantly lower ratio with a faster consolidation tendency. The Czech government debt-to-GDP ratio has decreased cumulatively by 11.4 pp over the past six years, almost two times faster than that of Slovakia (5.5 pp). This fact is reflected in the differences illustrated by the fiscal space indicator (right panel). A slower decreasing trend left Slovakia facing the onset of the coming economic slowdown with a fiscal cushion of $12 \mathrm{pp}$ compared to the Czech Republic's $29.2 \mathrm{pp}$.

Graph 2. Breakdown of factors affecting year-on-year change in government debt-to-GDP ratio (in pp)

Czech Republic (in pp)

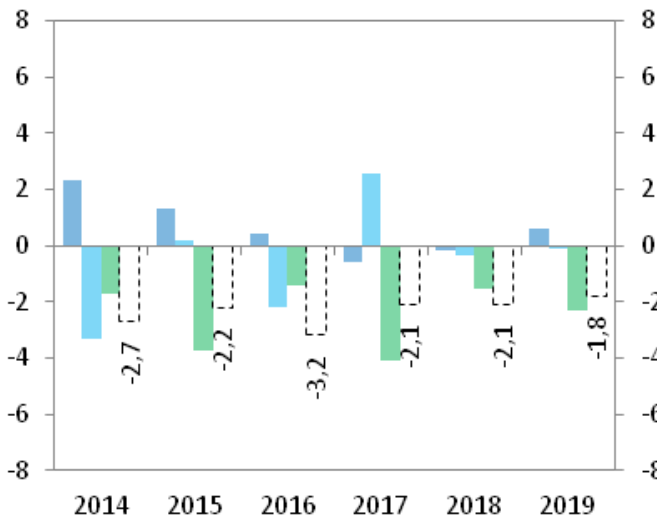

๓Central Government D eficit

mother

aDP

[] General Government Debt-to-GDP ratio change
Slovakia (in pp)

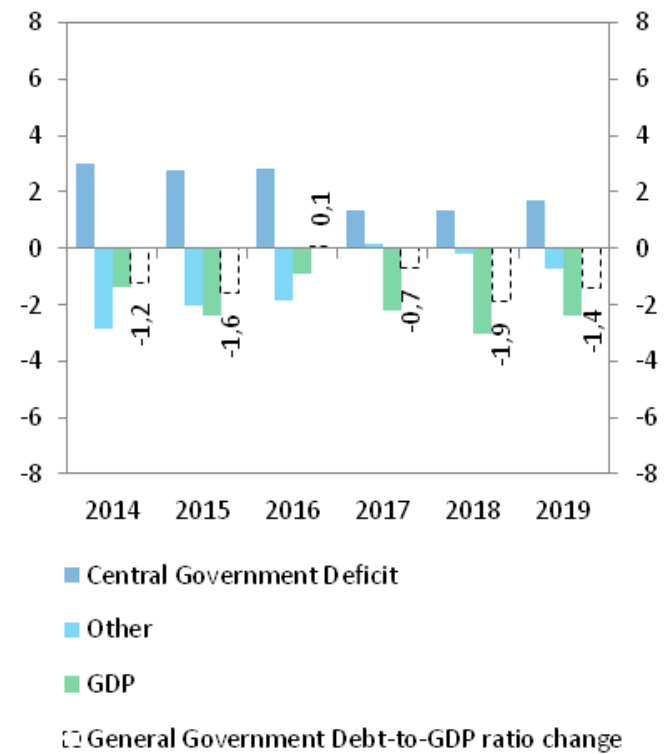




\begin{tabular}{|c|c|c|c|c|c|c|c|c|c|c|c|c|c|}
\hline CZ (in pp) & 2014 & 2015 & 2016 & 2017 & 2018 & 2019 & SK (in pp) & 2014 & 2015 & 2016 & 2017 & 2018 & 2019 \\
\hline $\begin{array}{l}\text { Central } \\
\text { Government } \\
\text { Debt effect }\end{array}$ & 2,32 & 1,32 & 0,44 & $-0,57$ & $-0,18$ & 0,60 & $\begin{array}{l}\text { Central } \\
\text { Government } \\
\text { Debt effect }\end{array}$ & 3,0 & 2,8 & 2,8 & 1,3 & 1,3 & 1,7 \\
\hline Other & $-3,34$ & 0,20 & $-2,21$ & 2,59 & $-0,37$ & $-0,11$ & Other & $-2,9$ & $-2,0$ & $-1,8$ & 0,1 & $-0,2$ & $-0,7$ \\
\hline $\begin{array}{l}\text { GDP change } \\
\text { effect }\end{array}$ & $-1,69$ & $-3,72$ & $-1,44$ & $-4,12$ & $-1,55$ & $-2,28$ & $\begin{array}{l}\text { GDP change } \\
\text { effect }\end{array}$ & $-1,4$ & $-2,4$ & $-0,9$ & $-2,2$ & $-3,0$ & $-2,4$ \\
\hline $\begin{array}{l}\text { General } \\
\text { Government } \\
\text { Debt-to-GDP } \\
\text { ratio change }\end{array}$ & $-2,70$ & $-2,20$ & $-3,20$ & $-2,10$ & $-2,10$ & $-1,80$ & $\begin{array}{l}\text { General } \\
\text { Government } \\
\text { Debt-to-GDP } \\
\text { ratio change }\end{array}$ & $-1,2$ & $-1,6$ & 0,1 & $-0,7$ & $-1,9$ & $-1,4$ \\
\hline
\end{tabular}

to-GDP ratio. Other includes local government debt effect and stock-flow adjustments

By breaking down the overall indicator into the partial effects of latent variables (Graph 2) we wanted to analyze the underlying dynamics of central government debt and their influence on the abovementioned decrease in debt-to-GDP ratios. In both countries the breakdown indicates the strong positive effect of economic growth and only a marginally positive (in the case of the Czech Republic) or outright negative effect (in the case of Slovakia) of actual central government debt lowering efforts.

The beginning of the period is characterized by central government actions that led to increasing debtto-GDP ratios. We can observe that their magnitude decreases over time while their effects dip only marginally into negative territory (decreasing the overall debt-to-GDP ratio in the years 2017 to 2018, in case of the Czech Republic), or remain positive during the entire period.

Overall positive economic sentiment is therefore the main driver of the debt-to-GDP ratio. Its effect in both countries remains stronger than any central government consolidation efforts. While the Czech Republic recorded positive effects of between 1.4 to $4.1 \mathrm{pp}$, in Slovakia the effects were of a narrower range (0.9 to $3.0 \mathrm{pp})$.

We can therefore conclude that, despite the ubiquitous claiming of fiscal responsibility by both Czech and Slovak politicians, the factor analysis suggests that it was the growth phase of the economic cycle, not governmental fiscal restraint, that played the key role in lowering the debt-to-GDP ratios.

\section{The ability to respond with central government stimulus}

The government deficits (or in the ESA2010 definitions Government net lending $\left(+\right.$ )/borrowing $\left.(-)^{1}\right)$ is the second key indicator used in the Growth and Stability Pact. The resulting Maastricht threshold of

\footnotetext{
1 Please note, that the indicators used in analysis are based on the government debt and government deficit in line with ESA2010 methodology. The variables are selected to document the development of the fiscal policy with respect to sovereign debt as well as to assess country's space to manoeuvre in and its probability of breaching of the Maastricht criteria (The legal basis of the SGP is represented by Articles 121 and 126 of the Treaty on the Functioning of the European Union. Fiscal thresholds are specified in the Protocol No. 12 on the excessive deficit procedure). Specifically, we would like to highlight that the time series of the indicator net
} 
$3 \%$ of GDP is the second hurdle to which we approximate our analysis. The government deficits thus document the economic policy of each government so far and predicate its ability to react in response to crisis.

Graph 3. Central government net lending (+)/net borrowing (-) in 2008-2019 (in mil. EUR); General and Central government deficit-to-GDP ratio in 2014-2019 (in \%)
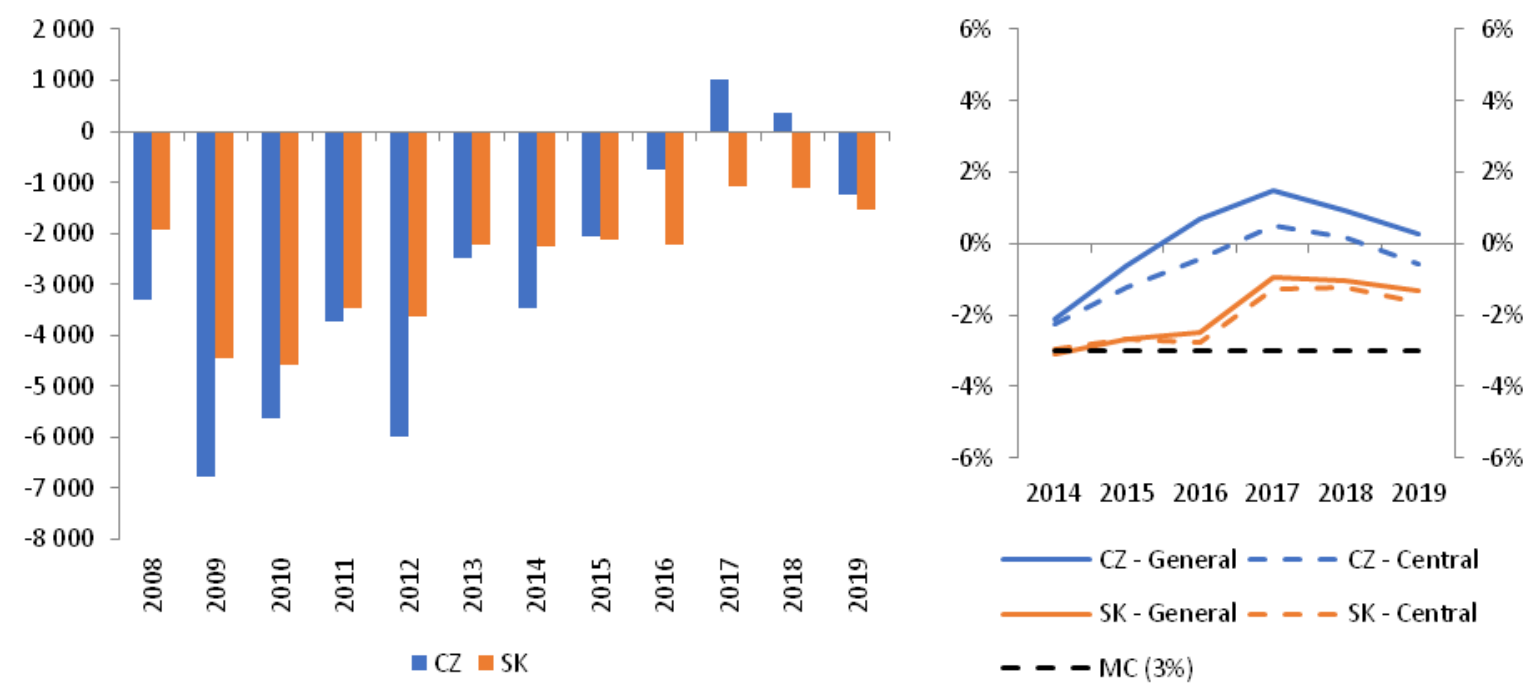

Source: Eurostat 2020 and own calculations.

The left panel of Graph 3 documents the evolution of the central government deficit/surplus over the time horizon of 2008 to 2019. After the initial expansive reactions to the crisis of 2008, we can observe a decreasing tendency for both state deficits in nominal terms. The period between 2014 and 2019 is characterized by lower government deficits in both countries and even two surplus years in the case of the Czech Republic while Slovakia consistently reports government borrowing, even in times of relative economic growth. Despite efforts realized to balance budgets in 2017 and 2018, both countries show an increase in central government deficits in 2019. The right panel in Graph 3 shows the nominal values as a share of GDP in current prices. Although the Czech general government deficit-to-GDP ratio (blue line) remains above the Maastricht threshold, the Slovak ratio (orange line) remains close to the threshold of 3\% from 2014 to 2016, only moving further away towards 2017. After the initial improvement in 2017 the Slovak ratio remains stable at around 1\% of GDP then decreases slightly in 2019 (-1.6\%). The Czech ratio overshoots to a surplus of just below 2\% (lending) of GDP before falling

lending/borrowing does not correspond to a state budget or its deficit development. As the most vivid example, this difference is manifested in years 2016 and 2017 in case of the Czech Republic. Whereas the infamous state surplus has been recorded in the state budget of 2016, the increase in net lending of Czech general government has manifested itself in 2017. With this knowledge we decided to focus the discussion on the Maastricht criteria relevant indicators, and only in the significant cases to include commentary on the state budgetary actions themselves. For the discussion of various definitions of government deficit please consult (Vebrová \& Rybáček, 2014). 
back towards a positive zero (+0.3\% of GDP in 2019). The dashed lines represent the central government deficit-to-GDP ratio and mirror the evolution shown in the left panel.

Graph 4. Breakdown of general government debt (in mil. EUR)

Czech republic (in mln. EUR)



Slovakia (in mln. EUR)

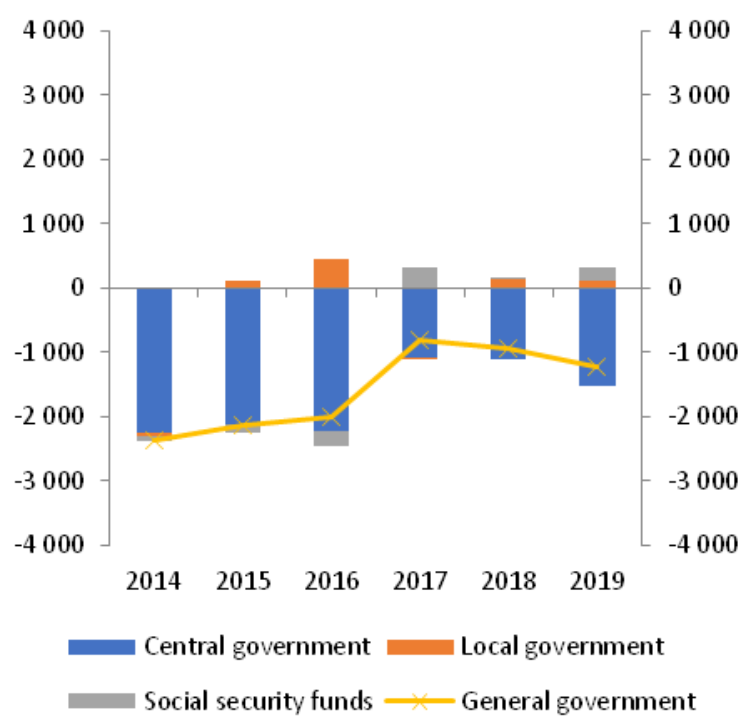

Source: Eurostat, 2020, The general government deficit/surplus is defined by the Maastricht Treaty as general government net lending (+)/net borrowing (-) according to the European System of Accounts. The general government sector comprises of central government, state government, local government, and social security funds

To expand the analysis, we broke down the general government deficit into central government lending/borrowing, local government lending/borrowing and social security funds contributions (the state government lending/borrowing category is not reported by both of the countries). The breakdown reveals the striking influence of local government lending in the Czech Republic. The impact is especially visible in the years between 2016 and 2019. Not only does local government lending exceed central government borrowing and successfully support the overall ratio but it also pushes central government borrowing in the years between 2016 and 2019 into positive territory. Any such supportive effects of the local government budget are largely absent in Slovakia.

Based on the Maastricht definition of general government deficit, we can conclude that the Czech Republic is generally better positioned at the onset of the crisis due to the recorded total surpluses in 2016-2019. Despite the 2017-2019 improvement, Slovakia remains within borrowing territory. However, the breakdown shows the substantial supportive effect of local government lending in the case of the Czech Republic. Considering the fact that central government budgets are usually used for providing fiscal impulses (due to possible legal restrictions on local government spending and substandard mechanisms of fiscal impulse distribution), the effect of the local government fiscal buffer may prove to be limited. Taking this into account and restricting the indicator to central government lending/borrowing only puts both countries in borrowing territory in 2019. This means that, from the 
viewpoint of overcoming the crisis caused by the COVID-19 pandemic shock, the advantage of the Czech fiscal starting position largely evaporates and remains only minimal.

\section{Fiscal policy stance relative to the position in the business cycle}

We looked at discretionary fiscal policy measures by analyzing the relationship between the change in the primary structural balance and the output gap. A comparison was made for the pre-crisis periods of 2005-2008 and 2016-2019. In this way we can measure the suitability of fiscal policy in relationship to the economic cycle. The Czech Republic was above its potential output for most of the selected period and we identified a positive production gap. Overall, fiscal expansion appeared to have a destabilizing effect on the economic cycle. Therefore, this same fiscal expansion may limit the scope for using discretionary fiscal stimulus measures for future active fiscal policy.

Graph 5. Relationship between primary structural balance change and the output gap
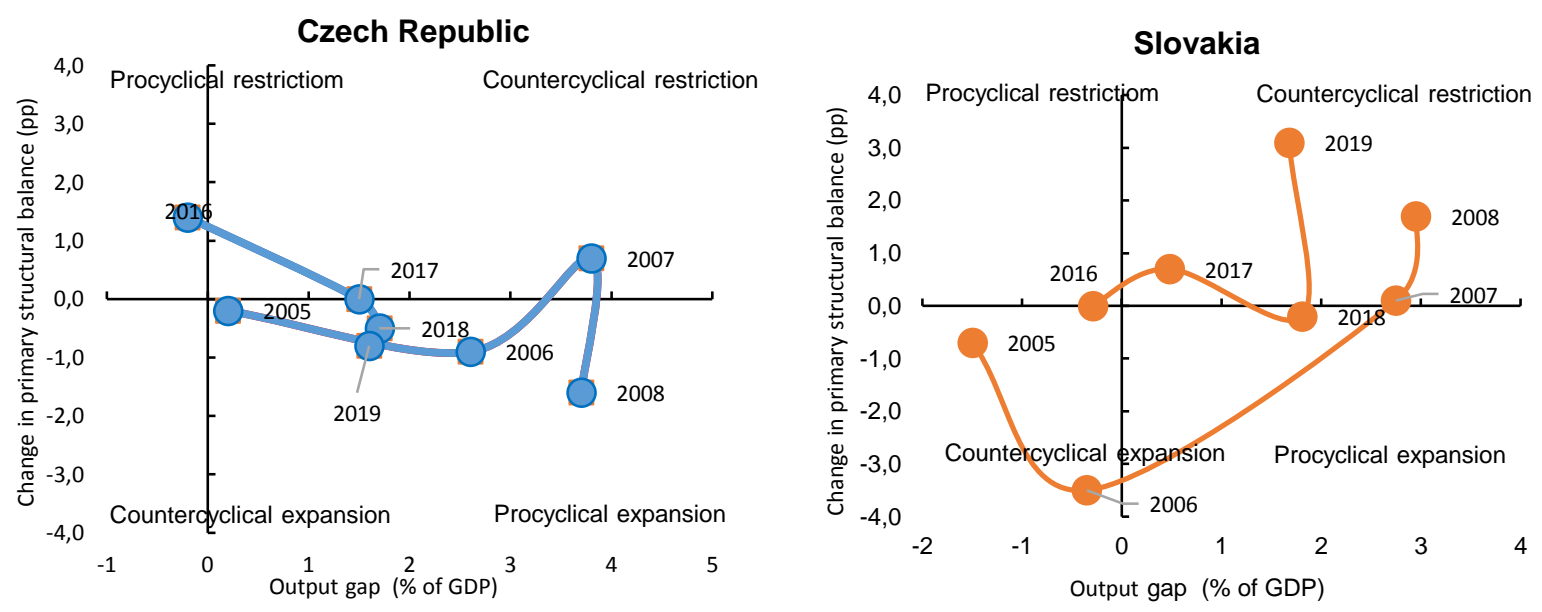

Source: MF ČR, Rojiček, M. et al: Makroekonomická analýza, teorie a praxe, MF SR, MF ČR, and own calculations

Graph 5 reveals that the Slovak economy also rose above its potential output for most of the reviewed period. Fiscal policy implemented in both pre-crisis periods had a countercyclical effect for most of the years observed and the stabilizing function of discretionary measures was preserved.

\section{Discussion}

In the previous sections, we presented an overview of the development of selected indicators, which can specify the areas in which the economy is relatively better or worse prepared for the looming crisis. Naturally, these examined indicators have their limits and the entire subject retains its highly complex character, rising from the great complexity and interconnectedness of the whole economy itself.

In the Czech Republic and in Slovakia, we could observe different approaches to the setting of fiscal policy throughout the monitored period. In the Czech Republic, the influence of the left-wing government enacting high state budget deficits in times of rapid economic growth is particularly 
evident in the years 2006 and 2007. In this same period, Slovakia is focused on preparation for entry into the third phase of ERM II and a systematic effort to reduce the state budget deficit.

In the financial crisis context, the processes associated with Slovakia's preparations for the eurozone membership were positive and, over a four-year period, Slovak public finances were relatively better prepared than the Czech ones. The years 2016 to 2019 revealed a contrary picture, with efforts exerted in the Czech Republic to balance the economy which led to the state budget being closed with a surplus in 2016 and $2018 .^{2}$ A boost was provided by resources from European funds in 2016. In recent years, the Czech Republic can also be characterized by an underestimation of state budget revenues, which has ultimately led to a positive distortion of financial results (Morda, 2019). However, the above findings show that if the general government deficit is broken down, the positive balance of the Czech Republic in 2016 to 2019 is strongly positively affected by a surplus at the level of local government institutions, which exceeds the central government deficits. As a deficit country according to the Maastricht criteria, Slovakia has a relatively worse starting position.

Another indicator also shows that Slovak public finances were relatively less prepared than the Czech one for the economic crisis caused by the exogenous shock in the form of the spread of COVID-19. While in the Czech Republic the ratio of public debt to GDP decreased inbetween 2014 to 2019 by an average of $1.9 \mathrm{pp}$ per year, in Slovakia this indicator decreased at an average rate of $0.9 \mathrm{pp}$ per year. The resulting $30.8 \%$ of the Czech Republic's GDP, compared to $48 \%$ of Slovakia's GDP, sends an important signal not only to investors regarding the state of public finances.

The crisis readiness of public finances can also be analyzed by focusing on another of the selected indicators, state budget balance. Among other things, this indicator partly reflects government efforts to consolidate public finances. In the years 2014 to 2019, the Czech Republic showed a surplus state budget on two occassions. Although half the size of the Czech economy, at this time the Slovak economy was continuously generating budget deficits. A simple conclusion that the Czech Republic was clearly better prepared for the coming crisis suggests itself but the issue is significantly more complex and Czech public budgets also have their problems. When considering the context of local government surpluses in the Czech Republic, it becomes impossible to state that a significant fiscal cushion, which would drastically mitigate the impact of the entire crisis, has been accumulated.

It is also very important to evaluate fiscal policy within the economic cycle by the timing and direction of its enactment. The reactions of Slovak fiscal policy architects were relatively more in line with the

\footnotetext{
${ }^{2}$ The goverment budget recorded its last surplus during the tenure of Prime Minister V. Klaus.
} 
actual phase of the economic cycle and, in contrast to Czech governments, they managed to set a counter-cyclical direction more often.

Despite the above, the Government of the Czech Republic decided to change the rules of budgetary responsibility ${ }^{3}$, which it subsequently (despite the opposition of the Senate) also achieved. ${ }^{4}$ The National Budget Council does not consider the loosening of the legal rules for 2021 and subsequent years to be suitable. In fact, it does not consider this rapid change in the rules of budgetary responsibility to be at all necessary and stressed that the law already contained (and contains) a number of institutes that allow the government to respond to emergencies (and thus violate the structural deficit rule of $1 \%$ of GDP)..$^{5}$ It can be noted with interest that the government's proposal to change the rules of budgetary responsibility was paradoxically not consulted at all with the National Budget Council. Amongst other things, this is pointed out in the legal analysis by Vondráček (2020), which adds that the amendment to the law also established norms for the 2022 to 2027 period and does not address the principles of budgetary responsibility as was intended by the Czech legislator, (that the bodies compiling and approving public budgets then subsequently managing them should behave "... in such a way to avoid inefficiencies and to ensure that budgetary management is balanced in the long run...."6). This raises the question of how strong (and stable) the rules of budgetary responsibility are in the Czech Republic when they can be so easily and widely changed when the crisis is still in initial response phase and sufficient data about the impact on the economy is not yet available. The question of anchoring these rules in the constitution itself, which was the approach chosen by Slovakia. The strength of the Consitutionsal Act was disscussed during the adoption of the Czech Act on the Rules of Budgetary Responsibility, and we cannot omit to mention that the during the debate in the Senate of the Parliament of the Czech Republic, opinions emerged stating that budgetary rules should not be fixed in law as they are purely a sovereign political matter.

The problem of economic policy in the Czech Republic in connection with the violation of the Act on Budgetary Responsibility also lies in the absence of a wider strategy or deeper concept of fiscal policy expenditures. As such there is a lack of a foundation on which the impacts of planned government

\footnotetext{
${ }^{3}$ Act No. 23/2017 Coll., On the Rules of Budgetary Responsibility, wording of later regulations

${ }^{4}$ The amendment to the Act on the Rules of Budgetary Responsibility was submitted as a government bill (Government Resolution of 1 April 2020, No. 367) and the Chamber of Deputies approved the draft amendment (Resolution of 8 April 2020, No. 1038). Subsequently The Senate of the Parliament of the Czech Republic rejected the draft amendment (resolution of 17 April 2020, No. 356) and, after returning the proposal to the Chamber of Deputies, it was approved definitively (resolution of 22 April 2020, No. 1083) but by a narrow majority (101 for, 83 against).

${ }^{5}$ UNRR press release of 3 April 2020

${ }^{6}$ KARFÍKOVÁ Marie a kol. Teorie finančního práva a finanční vědy. 1. vydání. Praha: Wolters Kluwer ČR a.s., 2018. 356 s. ISBN 978-80-7552-935-0. str. 164.
} 
expenditures could be analyzed and expert discussion conducted. At present, spending to support the real economy is around $1 \%$ of GDP. Furthermore, these expenditures are generally of a consumption nature and targeted at households. Another issue manifests itself in the massive increase in state debt planned for the coming years. Klaus (2020) draws attention to the problem of creating large debt for future generations and warns against possible disruption of public finances.

The entire fiscal policy is, of course, associated with other structural problems, such as the aging of the population and the resulting expense of pension system financing, or the actual composition of government expenditures, where mandatory and quasi-mandatory expenditures account for about $80 \%$ of total state budget expenditures. In this context, we can note the limited room to manouvere of fiscal policy and what coud be called the loss of fiscal democracy. When taking measures aimed at mitigating the effects of the crisis, it is also very important to focus on the supply side of the economy, especially reducing the tax burden, eliminating and reducing selected tax rates or aborting the next phase of electronic sales record introduction (Ševčík et al, 2020).

\section{Conclusion}

By definition, an exogenous shock finds the economy and its actors "unprepared". The question that remains, however, is whether a responsible fiscal policy can partially protect the economy from the negative effects of the crisis such a shock creates. An overall comparison shows that the Slovak economy is relatively less prepared than the Czech one. Mainly due to a higher ratio of public debt to GDP and the higher economic deficits of government institutions. We can view this as Bastiat's "that which is seen". What is not obvious at first glance is the inability of Czech governments to focus their fiscal policy in a counter-cyclical direction to help smooth economic cycles. In this respect, Slovak governments were more successful. The breakdown of the debt reduction trend in relation to GDP also shows that the key factor influencing the development of this indicator was primarily GDP dynamics and not the politically proclaimed government restrictions. In addition to this, the breakdown of government debt itself shows that the dominant factor influencing the surplus reported by Czech government institutions was the positive performance of local government. The fact remains that Slovakia performed significantly worse with permanent deficits. Another problem discussed is the change of budgetary responsibility rules, as the Government of the Czech Republic managed to enforce an amendment to the law in an accelerated procedure, despite the Senate's disapproval. This questions the importance and robustness of rules that can be so easily changed and the set limits relaxed. It is also legitimate to question whether the principles of budgetary responsibility rules have been violated. 
"We have not heard the ambition - neither from the government nor from the opposition - to significantly reconsider the distribution of taxpayers' money, we have not heard of a plan for a major overhaul of budgetary priorities and therefore spending. Any government financial project today must be not only about new expenditures, but also about cuts in existing expenditures. Normally we would also talk about budget revenues, but there is not much space here and there will not be." (Klaus, 2020) It all has a purely financial aspect ... but it has another aspect: knowing state spending is nothing more than the installation of a strong state, an expansive state, a self-reproducing state. More state means less space for individual activities. It also means more envy, more selfishness, more corruption, more accusing and denouncing." (Klaus, 2020)

\section{References}

Buchanan, J., Tullock, G. The Calculus of Consent: Logical Foundation of Consttutional Democracy, Ann Arbor: University of Michigan Press, 1962

Cline, W. R. International Debt Reexamined. Washington: Institute for International Economics, 1995 Dornbusch, R. Claessens, S. a Park, Y.-Ch. 2002, Contagion: How it Spreads and How it Can be Stopped. World Bank Research Oberver, May 2002

Dvořák, P. Veřejné finance, fiskální nerovnováha a finanční krize, 2008, Praha, C. H. Beck, 978-80-7400075-1

Guitian, M. Rules and Discretion in International Economic Policy, IMF Occasinal Papers, 1992, no. 97 KARFÍKOVÁ Marie a kol. Teorie finančního práva a finanční vědy. 1. vydání. Praha: Wolters Kluwer ČR a.s., 2018. 356 s. ISBN 978-80-7552-935-0.

KLAUS, Václav. Karanténa: přežije naše svoboda éru pandemie?. Praha: Institut Václava Klause, 2020. Publikace (Institut Václava Klause). ISBN 9788075420619.

Krugman. P.: The Return of Depression Economics, Penguin Group, 2000

MFČR Makroekonomicka predicke leden 2020

MILAN BEDNÁŘ (2018). Southern Countries of the European Union in a Debt Trap: What Options Are on the Table?. International Journal of Economic Sciences, Vol. VII(2), pp. 1-34. , DOI: 10.20472/ES.2018.7.2.001 
Ministerstvo financí České republiky. Fiskální výhled ČR. ISSN 1804-7998, [cit. 2020-06-18]. Dostupné z: https://www.mfcr.cz/cs/verejny-sektor/makroekonomika/fiskalni-vyhled/2019/fiskalni-vyhled-crlistopad-2019-36587

Ministerstvo financí České republiky. Makroekonomická predikce (2010, 2011, 2012, 2020). [cit. 202006-17]. Dostupné z: https://www.mfcr.cz/cs/verejny-sektor/makroekonomika/makroekonomickapredikce

Ministerstvo financií Slovenskej republiky. Fiškálne indikátory [online]. [cit. 2020-06-17]. Dostupné z: https://www.mfsr.sk/sk/financie/institut-financnej-politiky/ekonomicke-statistiky/fiskalneindikatory/

Ministerstvo financií Slovenskej republiky. Program stability na roky 2020-2023[online]. 05/2020 [cit. 2020-06-17]. Dostupné z: https://www.mfsr.sk/sk/financie/institut-financnej-politiky/strategickematerialy/program-stability/program-stability.html

MIROSLAV SEVCIK, ADELA ZUBIKOVA, JOSEF KLEMENT, JAN KOZAK, MARTIN ZEMAN, PAVEL SMOLAK, TOMAS LEJSEK, LUBOR SIMUNEK, KRISTYNA VESELA (2020). Economic Policy Recommendations During the Coronavirus Pandemic in the Czech Republic. International Journal of Business and Management, Vol. VIII(1), pp. 155-175. , DOI: 10.20472/BM.2020.8.1.008

Mishkin, F. S. Financial Policies and the Prevention of Financial Crises in Emerging Market Ecoomies. World Bank Policy Research Working Paper, October 2001, no. 2683

MORDA, Pavel. Vývoj státního dluhu České republiky: Úřad Národní rozpočtové rady - Informační studie [online]. In: . 06/2019, s. 15 [cit. 2020-06-18]. Dostupné z: https://unrr.cz/wpcontent/uploads/2019/06/Informa\%C4\%8Dn\%C3\%AD-studie_V\%C3\%BDvoj-st\%C3\%A1tn\%C3\%ADhodluhu-\%C4\%8Cesk\%C3\%A9-republiky.pdf

Peltzman, S. Toward a More General Theory of Regulation. Journal of Law Economic, April 1976, no. 19. p. $109-148$

Radetel, S., Sachs, J. 1998. The Onset of the East Asian Financial Crisis. Harvard Institute for International Development, NBER Working Paper, March 1998

ROJÍČEK, Marek, Vojtěch SPĚVÁČEK, Jan VEJMĚLEK, Eva ZAMRAZILOVÁ a Václav ŽĎÁREK. Makroekonomická analýza: teorie a praxe. Praha: Grada Publishing, 2016. Expert (Grada). ISBN 97880-247-5858-9.

Stigler, G. The Theory of Economic Regulation. Bell Journal of Economic and Management Science, 1971, no. 2. p. 3-21 
ŠEVČíkOVÁ, Michaela. Five crises of the European integration process. Praha: Oeconomica, nakladatelství VŠE, 2015. ISBN 978-80-245-2098-8.

ÚŘAD NÁRODNÍ ROZPOČTOVÉ RADY. Vyjádření Národní rozpočtové rady k vládnímu návrhu změny zákona č. 23/2017 Sb., o pravidlech rozpočtové odpovědnosti [online]. 3.4.2020 [cit. 2020-06-18]. Dostupné z: https://unrr.cz/tiskove-zpravy/

Vebrová, L., Rybáček, V. How to Read Government Deficit and Debt. Statistics and Economy Journal Vol. 94 (3) 2014, 2014, ISSN 1804-8765 